\title{
Focus on Form Techniques in Second Language Teaching
}

\author{
Yuanqing Huang \\ School of Foreign Languages, Neijiang Normal University \\ Neijiang, Sichuan, China \\ School of Foreign Languages, Chongqing Normal University \\ Chongqing, China \\ Email: huangyq629@126.com
}

\begin{abstract}
As a second language teaching method, Focus on Form has aroused great enthusiasm among second language acquisition researchers and teachers since its proposal at the end of the last century. Most previous researches have proved that Focus on Form is effective in promoting both learners' accuracy and fluency in second language acquisition. On this basis, this study is carried out to collect and summarize all the practical techniques scattered in different research papers. These techniques can be of some help when language teachers decide to adopt Focus on Form in classroom language teaching. By reviewing all the available literature related to Focus on Form, this paper presents a collection of practical Focus on Form techniques which are expected to provide some convenience for Second Language Teachers as they adopting this method to improve their teaching efficiency.
\end{abstract}

Keywords-Focus on Form; Focus on Forms; Focus on Meaning; Second Language Teaching

\section{INTRODUCTION}

Focus on Form (FonF) is an eclectic approach in Second Language Teaching (SLT) which is closely connected with but also different from both Focus on Forms (FonFS) and Focus on Meaning (FonM) instruction. Focus on Forms (for example, traditional grammar teaching method) puts emphasis solely on language forms, ignoring the cultivation of language learners' communicative competence, which directly leads to students' inability in applying language forms in communicative practice although they can achieve high marks in exams. Focus on Meaning (for example, communicative approach), on the other hand, focuses merely on the development of communicative competence, neglecting form instruction. In consequence, students trained with this kind of method can use the target language in communicative activities, but usually with quite a lot of mistakes, which in return limits the communication of meaning. Therefore, both Focus on Forms and Focus on Meaning are defective. A new and better second language teaching method is desperately needed.

Due to the failure of Focus on Forms and Focus on Meaning, in 1991, Michael Long put forward Focus on Form with an aim to provide an eclectic approach between these two extremes in language teaching. Focus on Form advocates that learners' attention should be deliberately directed to linguistic forms when they incidentally arises in activities whose overriding focus is on meaning and communication. Focus on Form tries to combine the advantages of both Focus on Forms and Focus on Meaning and develops students' fluency and accuracy at the same time [1].

Since Focus on Form was brought about, it has experienced a lot of theoretical and empirical studies by researchers and language teachers at home and abroad. Some researches explored the theoretical foundation of Focus on Form. Some others investigated its effectiveness through empirical experiment. Most of these studies found that Focus on Form was an effective approach for Second Language Teaching. But at present, researches focus on the implementation of Focus on Form in classroom teaching are still not sufficient. Based on the previous studies, this paper aims to summarize all the concrete Focus on Form techniques in classroom teaching proposed in the related literature, which may provide some convenience to the Second Language Teachers who hope to have a better use of Focus on Form approach and promote their teaching outcome.

\section{FOCUS ON FORM-AN EFFECTIVE TEACHING APPROACH IN SECOND LANGUAGE TEACHING}

The theoretical foundation of Focus on Form is mainly the Noticing Hypothesis and Interaction Hypothesis.[2] The Noticing Hypothesis was proposed by Richard Schmidt in 1990, which holds that learners cannot learn the grammatical features of a language unless they have noticed them.[3] Noticing is the core of second language acquisition and is the necessary and sufficient condition for input to be converted into intake. But due to the limited language processing ability of second language learners, they can hardly notice meaning and form at the same time and usually meaning is in priority of form [4]. The allocation of noticing resource is the critical issue of Focus on Form. Focus on Form adopts certain methods in meaning-centered activities to direct learner's attention from meaning to forms that arise during the communicative process in order to help learners acquire language accuracy as well as fluency.

Focus on Form is directly derived from the Interaction Hypothesis. The Interaction Hypothesis states that the development of language proficiency is promoted by face-to- 
face interaction and communication, especially the interaction and communication with those who are higher in language proficiency, or through the interactive activities with deliberately designed written or listening material. The negotiation of meaning arises in the interactive activities which can greatly increase students' attention to form, and therefore, language input, learners' inner language processing ability and language output are organically combined together through this kind of interaction and communication. This greatly helps students to notice the differences between their inter-language and the target language, then bring possibility for "pushed output", and finally promote the accurate acquisition of language forms in meaning-based activities.

Most researches on the efficacy of Focus on Form in second language acquisition have revealed positive results in promoting learners' accuracy in language forms during meaning-centered communicative activities. For instance, Leowen. S. (2004) found that the target forms dealt in Focus on Form could be somewhat up-taken by the students; [5] Williams. J. (2001) discovered that the students with higher language proficiency got higher accuracy on the forms that were the targets of Focus on Form;[6] Tian Lili (2011) of China researched in the influence of Focus on Form on the receptive vocabulary and found that the students in the Focus on Form group scored significantly higher in both the immediate and delayed post tests than in the pretest, and they also scored significantly higher than those in the Focus on Meaning group in the delayed post test [7]. This research showed that Focus on Form was effective in the study of receptive vocabulary and it was more effective than Focus on Meaning. Another Chinese researcher, Wang Yinghua's experiments revealed that Focus on Form had significant effect in improving students' English language competence [8].

Since so many empirical studies at home and abroad have proved that Focus on Form is a better choice for language teaching than the traditional Focus on Forms and the radical Focus on Meaning, this paper makes an effort to review all the available literature related to Focus on Form and summarize every practical technique of carrying out the approach of Focus on Form in language teaching. These techniques will for sure be helpful to teachers who hope to employ Focus on Form approach in their language teaching.

Focus on Form is categorized into Reactive Focus on Form and Proactive Focus on Form according to whether the target language forms are prepared beforehand or arise incidentally while meaning-based or communication-centered classroom activities. In the following two parts, the techniques employed in Reactive Focus on Form and Proactive Focus on Form will be presented respectively.

\section{THE TECHNIQUES EMPLOYED IN REACTIVE FOCUS ON FORM}

Reactive Focus on Form is a method by which teachers briefly and overtly shift away students' attention from meaning to some linguistic code features which are triggered by perceived problems with comprehension or production by the teacher and/or one or more students. Michael Long thinks that this kind of attention to form triggered by difficulties in communication is especially salient. It is the salience and communicative needs that provide ideal precondition for the generation of notice and acquisition.[9] Reactive Focus on Form is widely used in oral communication activities. The following techniques can be employed in Reactive Focus on Form:

\section{A. Negotiation}

Negotiation is divided into Negotiation of Meaning and Negotiation of Form, which have different cause and different purpose.

Negotiation of meaning happens when a language learner's verbal output leads to failure of communication, then the teacher or the other speaker of higher language proficiency negotiates with the learner about meaning in order to overcome the obstacles in communication. The cause of negotiation of meaning is the failure of communication and the purpose is to promote understanding.

Negotiation of form happens when there is no obstacles caused by a learner's verbal output, and the teacher negotiates with the learner about some forms which are improperly used with an intention to improve the learner's language accuracy. The cause of negotiation of form is improper use of the target language and the purpose is on the promotion of the learner's language accuracy.

\section{B. Request for confirmation}

Request for confirmation refers to that when some language mistakes appear in a learner's verbal output, the teacher or the other speaker of higher language proficiency repeats the problematic part and tries to make this part salient by various means, such as reading with special stress, lengthening the syllables, changing the tone, and so on, to draw the learner's attention to form.

This kind of method is usually applied to comparatively simple mistakes or errors and learners can realize and modify the mistakes or errors by themselves when the teacher requests for confirmation. This technique is good for learners to get rid of such easy or usually unconscious mistakes or error gradually in their communication. 


\section{Request for clarification}

Request for clarification refers to that when there is a difficulty caused by a learner's mistakes about language pronunciation, such as mispronunciation, accent, vague pronunciation, and so on, the teacher requires the learner to repeat to clarify the original meaning that the learner wants to express by questions like "What? / Pardon? / What do you mean by ...", and so on. This kind of method can help the learner to notice the problems exist in their pronunciation and therefore make an effort to come over the problems.

\section{Recast}

Recast refers to that the teacher repeats a whole sentence of a learner or just part of it when there is a language mistake in it. By recast, the teacher does not point out the mistake explicitly but directly provide the learner with the correct form. For example, when a student says, "I am come from Neijiang city." the teacher may repeat the student's sentence but with the mistake corrected like this, "I come from Neijiang city."

Michael Long pointed out that recast can provide students with understandable form-focused input and thus is helpful to the development of a second language [10]. The teacher can make the recast of the mistake more explicit by putting stress on the correct form, lengthening the syllable of the correct form, changing tone of the target word, and so on, to draw the learner's attention to target language form.

Without obviously pointing out the learner's mistake, the technique of recast would not hurt the learner's self-respect as other techniques may do. However, it may often be ignored by learners because it is inexplicit. Therefore, the effect of recast may not be prominent.

\section{E. Correction}

Different from recast, correction refers to that the teacher explicitly points out the mistake in a learner's output and corrects it.

There's no doubt that the learner will immediately realize his or her misstate, however, this kind of method is not suitable to be used in public in case it may embarrass the learner and hurt the learner's self-respect. It is better applied to teacher and students who are well-related and have mutual trust or to students who are outgoing and psychologically well-built. And to students who are introverted and sensitive or who have low self-esteem, this kind of technique is forbidden.

Used properly, correction can make students notice the gap between the target language and their inter-language, and therefore develop their inter-language effectively.

\section{F. Elicitation}

Elicitation is a method by which the teacher doesn't provide the student with a correct form when some mistake arises in the student's output, but just tries to elicit the correct form from the student by specific skill or expression. For example, when a student made a mistake, the teacher may use questions like "How do we say ... in English?" , "How to express ... in English?", "Is ... a verb / noun /...?", and so on, or the teacher may just pause to make the student fill out the correct form and thus elicit self-modification from the student.

This kind of technique is also more suitable for easy mistakes or errors, in which the teacher adopt specific skill to shift the language learner's attention to form and make him or her to reflect on their output and finally correct the mistake or error by themselves.

\section{G. Meta-linguistic feedback}

Meta-linguistic Feedback refers to that the teacher questions, hints or comments on a learner's problematic output by using meta-language or explanation to elicit selfmodification from the learner. For example, the teacher may use sentences like "It happened yesterday, should we use present tense?", "Is 'person' an uncountable noun?", or "It happened yesterday, we should not use present tense.", " 'Person' is a countable noun." and sentences alike to elicit modification from the learner.

This kind of method is quite explicit and is easy to shift the students' attention to language form. But similar to correction, this technique should not be used in public to those who are sensitive and highly self-conscious to avoid embarrassing them and hurting their self-respective.

\section{The TeChniques EMPloyed in ProActive Focus on FORM}

The concept of Focus on Form was originally put forward by Michael Long (1991), which holds that focus on form is generated to meet the needs of communication and not prepared beforehand [11]. C. Daughty \& J. Williams (1998) expanded the category by defining Long's original Focus on Form as Reactive Focus on Form and put forward another category of Focus on Form, that is, proactive Focus on Form [12].

Proactive Focus on Form refers to that, on the basis of a good understanding of students' inter-language, the teacher prepares some target form or forms which are supposed to be problematic and arrange communicative tasks with these forms being the target forms to be focused on, and thus, students' attention will be briefly but deliberately shifted from meaning to the prepared language forms in the arranged communicative tasks. Compared with reactive Focus on Form which requires high proficiency of a second language on the teacher's side, proactive Focus on Form requires the teacher to have a good understanding of the state of learners' interlanguage.

Communicative tasks with proactive target forms require learners to focus on both meaning and form by using the proactive target forms to accomplish a communicative task or 
to achieve a communicative purpose. This kind of communicative tasks provide learners with a good opportunity to be exposed in the target language and to output their interlanguage and is also good for learners to notice during the communicative process the gap between their inter-language and the target language, which will finally contribute to the improvement of learners' language fluency and accuracy.

R. Ellis (2001) advocates that proactive Focus on Form promotes learners' acquisition of language forms through communicative process because "pushed output is generated by the prepared input in proactive Focus on Form. The core of proactive Focus on Form is to prepare target forms and effective implementation measures to shift students' attention from meaning-based or communication-centered activities to the prepared target language forms [13].

The core of proactive Focus on Form is communicative tasks with prepared linguistic forms. Communicative tasks with prepared linguistic forms are closely related to language input and output. Different techniques can be applied to both input and output process in order to make learners focus on forms during meaning-based activities.

Input is mainly realized through the ways of listening and reading. The techniques to call the learners' attention to the prepared linguistic forms in listening materials include such as repeating the target linguistic forms, reading the prepared forms with changed tone, special stress, lengthened syllables, and so on, to call the learners' attention. The teacher can also explain the forms witch are possible to make understanding difficult and thus affect communication before the communicative tasks. The prepared linguistic forms in reading material can be printed in black, bold, italics, or with capitalized, colored, underlined, or larger words, and so on, to draw learners' attention. The prepared forms can also be repeated for several times in reading materials to enhance the learners' attention to the target linguistic forms.

Output in communicative tasks is mainly oral or written. Teachers can design oral and written tasks which involve the planned target forms. According to J. Williams (1995), tasks can be divided into three stages [14].

The first stage is pre-task. In this stage, some techniques can be adopted to help the learners focus their attention on the planned linguistic forms, for example, when the teacher assigns a task to the students, the panned target forms can be hinted along with the requirement for accomplishing the task, or the teacher may explicitly require the learners to use certain linguistic forms when they carry out the communicative task.

The second stage is during-task. In this stage, the students are required to use the planned target forms to achieve the purpose of communication for meaning. This stage is aimed to make the learners be conscious of the target linguistic forms while doing the meaning-oriented activities, which is thought to be helpful for learners to develop both fluency and accuracy of their inter-language.

The third stage is post-task or language-focus. As the name suggests, this stage happens after the learners finish their task of communication and their focus will be completely shifted to the planned language forms. In this stage, the teacher analyzes students' application of the planned forms in the assigned oral or written tasks or give some explanation and examples of usage of the target linguistic forms. The purpose of this stage is to finally help the students acquire the usage of these planned target forms.

\section{CONCLUSION}

It has been more than twenty years since Focus on Form was first proposed by Michael Long in 1991, and it has been more than ten years since it was introduced to China. Focus on Form has aroused heated discussion and enthusiastic exploration by researchers and teachers in second language acquisition all over the world. Over these years, Focus on Form has gone through theoretical and empirical tests and has been proved to be positive in second language teaching and learning. At the present time, Focus on Form has been employed by a lot of second language teachers through out the world. Therefore, it's necessary to advocate this teaching method and to explore the concrete techniques to carry out this new method in classroom language teaching, which is not only helpful for second and foreign language teachers to improve their teaching efficiency, but also helpful for learners to attain better achievements in their language learning.

\section{ACKNOWLEDGMENT}

Yuanqing, Huang. 1975-, female, Associate Professor, Master of Arts, majored in Applied Linguistics, , Teaching college English at Neijiang Normal University, Sichuan province, China. Zip Code: 641112; Address: Room 1-10, Staff building No. 22, Eastern Campus, Neijiang Normal University, Sichuan province, China; Tel: +86 158848 37648; email: huangyq629@126.com; QQ: 360799935.

\section{REFERENCES}

[1] Michael Long. (1991). Focus on Form: A Design Feature in Language Teaching Methodology. In Bot, K. Ginsberg, R. \& Kramsch, C. (eds.). Foreign Language Research in Cross-Cultural Perspective. Amsterdam: John Benjamins, 69-74.

[2] Michael Long, P. Robinson. (1998). Focus on Form: Theory, Research, and Practice. In C. Doughty \& J. Williams (eds.), Focus on Form in Classroom Second Language Acquisition. Cambridge: Cambridge University Press, 15-21.

[3] Richard Schmidt. R. (1990). The Role of Consciousness in Second Language Learning. Applied Linguistics, 11,129-158.

[4] Van Pattern. B. (1996). Input Processing and Grammar Instruction in Second Language Acquisition. Norwood: Ablex.

[5] Loewen. S. (2004). Variation in the frequency and characteristics of incidental focus on form. Language Teaching Research, 7, 315-345.

[6] Williams. J. (2001). The Effectiveness of Spontaneous Attention to Form. System, 29, 325-340.

[7] Tian Lili. The Influence of FonF on Receptive Vocabulary in Second Language Acquisition. Foreign Languages and Their Teaching, 2011, 2: 52-56(in Chinese).

[8] Wang Yinghua.(2010). SPSS Assisted Analysis of the Effect of "Focus on Form". Journal of Taizhou Institute, 2, 48-52(in Chinese).

[9] Michael Long. (1991). Focus on Form: A Design Feature in Language Teaching Methodology. In Bot, K. Ginsberg, R. \& Kramsch, C. (eds.). Foreign Language Research in Cross-Cultural Perspective. Amsterdam: John Benjamins, 70. 
[10] Michael Long. (1991). Focus on Form: A Design Feature in Language Teaching Methodology. In Bot, K. Ginsberg, R. \& Kramsch, C. (eds.). Foreign Language Research in Cross-Cultural Perspective. Amsterdam: John Benjamins, 72.

[11] Michael Long. (1991). Focus on Form: A Design Feature in Language Teaching Methodology. In Bot, K. Ginsberg, R. \& Kramsch, C. (eds.). Foreign Language Research in Cross-Cultural Perspective. Amsterdam: John Benjamins, 70.

[12] Doughty, C., \& Williams, J. (1998). Pedagogical choices in focus on form. In C. Doughty, \& J. Williams (eds.), Focus on form in classroom second language acquisition. Cambridge: Cambridge University Press, 197-261.

[13] Ellis, R. (2001). Investigating Form-focused Instruction. Language Learning, 51, 1-46.

[14] Williams, J. (1995). Focus on Form in Communicative Language Teaching: Research Findings and the Classroom Teacher. TESOL Journal, 4, 12-16. 